Elżbieta CZARNY-DROŻDŻEJKO

Uniwersytet Jagielloński

elzbieta@drozdzejko.pl

\title{
PRAWNOKARNE OGRANICZENIE WOLNOŚCI WYPOWIEDZI W POLSCE (WYBRANE ASPEKTY)
}

ABSTRACT Penal limitation on freedom of expression in Poland (selected aspects)

The article titled "The Criminal Law restrictions on freedom of expression in Poland" concerns the issue of selected criminal offences to the press. Many legal rights must be protected by the norms and mores. Thus, journalists, and editors-in-chief must be aware of the possible criminal liability for violations. These regulations limit the freedom of expression, which, however, is not absolute. I think that the penalization of the abuse of freedom of expression is essential in today's society. However, it is the anachronism to predict, in some cases (e.g. defamation, insults), in relation to the press, the possibility of applying the imprisonment penalty. Therefore, I believe, that it is necessary to liberalize the Polish criminal law.

Keywords: media, freedom of expression, press offenses

Słowa kluczowe: media, wolność wyrażania opinii, przestępstwa prasowe

$\mathrm{P}$ rzestępstwa prasowe to czyny polegające na opublikowaniu lub nieopublikowaniu materiału prasowego, który narusza granice wolności prasy przewidziane w obowiązującym ustawodawstwie. Wolność prasy wywodzi się ze swobody wyboru formy wypowiedzi, która z kolei jest prawem do formułowania lub nieformułowania opinii i poglądów. Opinie i poglądy zasadniczo mają dotyczyć spraw istotnych dla społeczeństwa, a więc polityki, religii czy gospodarki. Z tego względu zarówno przestęp- 
stwa porządkowo-prasowe, jak i przestępstwa popełnione w treści materiału prasowego (niewłaściwe) mogą zostać objęte wspólną nazwą „przestępstwa prasowe”, gdyż są popełnione w wyniku działalności prasowej poprzez naruszenie prawnych ograniczeń wolności wypowiedzi.

Definiując z kolei przestępstwo prasowe niewłaściwe (popełnione w treści materiału prasowego), należy oprzeć się na kategorii ograniczenia wolności prasy ze względu na treść publikacji. Wolność prasy nie ma charakteru materialnego, a jedynie formalny. Jest poddana licznym ograniczeniom przewidzianym przez prawo ${ }^{1}$. Ograniczenia dotyczące treści publikacji są sformułowane w przepisach prawnych zarówno o charakterze karnym, jak i cywilnym, które zakazują rozpowszechniać określone treści. Aby można było mówić o przestępstwie prasowym, musi zostać naruszona norma sankcjonująca, a więc sprawca musi zrealizować czyn zabroniony opisany w przepisie karnym. Może ono zostać popełnione nie tylko za pomocą słowa, ale wszelkiego typu innych „wypowiedzi", a więc także za pośrednictwem gestu i obrazu. Jednakże nie każde przekroczenie ograniczające treść wypowiedzi można uznać za przestępstwo prasowe, a jedynie takie, które godzi w reguły kształtujące prawo społeczeństwa do informacji.

Najbardziej typowymi dla prasy są zniesławienie i wszelkiego typu zniewagi. W kodeksie karnym zostało uregulowanych jeszcze wiele innych typów czynów zabronionych, które mogą zostać popełnione za pośrednictwem prasy. Dodatkowo należy pamiętać, że wiele czynów zabronionych wymieniono w ustawach szczególnych.

\section{PRZESTĘPNE NAWOŁYWANIE, POCHWALANIE ORAZ PROPAGOWANIE}

Przestępne nawoływanie do popełnienia przestępstwa, pochwalanie przestępstwa lub propagowanie określonej ideologii, zwłaszcza gdy odbywa się za pośrednictwem prasy, może prowadzić do poważnych niepokojów społecznych i innych groźnych dla państwa konsekwencji (może je mieć np. nawoływanie do niepłacenia podatków). Dlatego ingerencja władzy publicznej w tych przypadkach jest jak najbardziej usprawiedliwiona. Podstawowymi dobrami prawnie chronionymi są w tym przypadku spokój i porządek publiczny. Aby te dobra chronić, ustawodawca wprowadził szereg czynów zabronionych, które popełnione za pośrednictwem prasy stają się przestępstwami prasowymi.

Przestępne nawoływanie można podzielić na przestępne nawoływanie do jakiejkolwiek zbrodni lub występku oraz kwalifikowane przestępne nawoływanie do szczególnej zbrodni lub występku. Odrębnie należy zinterpretować publiczne nawoływanie do nienawiści z określonych powodów. Sama bowiem nienawiść nie jest czynem zabronionym.

Nawoływanie może przybrać nie tylko postać audialną, chociaż z etymologii tego wyrazu można by tak wnosić, ale jakąkolwiek inną formę, np. druku, cyfrową, rysunko-

Zob. J. Barta, I. Dobosz, Prawo prasowe, Kraków 1989, s. 22-25. 
wą. Podobnie nawotywanie nie ogranicza się do wypadków, w których wyrażenie to miatoby zastosowanie literalne, dostowne, nie ogranicza się zatem do wypadków emisji gtosu podniesionego, do wotania ${ }^{2}$. Może więc nastąpić za pośrednictwem prasy drukowanej, ulotek, a także Internetu. W obu przypadkach może przybrać formę ilustracji, fotografii, grafiki. Wydaje się również, że nawoływanie może nastąpić za pomocą gestów czy języka migowego. Można więc przyjąć, że nawoływanie będzie polegało na posłużeniu się przez sprawcę wszelkimi znanymi ludzkości znakami; wydaje się jednak, że znaki te muszą być dla ich odbiorców zrozumiałe. Natomiast nie ma znaczenia środek użyty do komunikowania znaków. W sytuacji, gdy taki ustalony system znaków zostanie użyty w prasie, mamy do czynienia z przestępstwem prasowym.

Nawoływanie musi dotyczyć na gruncie art. 255 k.k. występku, zbrodni lub przestępstwa skarbowego. Chodzi więc o konkretny czyn zabroniony. Musi to być w takim wypadku nawoływanie do zabójstwa, kradzieży itp. Sprawca nie musi posługiwać się językiem ustawy³ zamiast określenia „zabójstwo” można więc na przykład użyć terminów „eksterminacja” czy „likwidacja”. Zamiast nawoływania do bójki można natomiast użyć zwrotów potocznych, na przykład „zadyma”.

Zgodnie $\mathrm{z}$ art. 7 k.k. zbrodnią jest czyn zabroniony zagrożony karą pozbawienia wolności na czas nie krótszy od lat 3 albo karą surowszą. Natomiast występkiem są czyny zabronione zagrożone grzywną powyżej 30 stawek dziennych, karą ograniczenia wolności albo karą pozbawienia wolności przekraczającą miesiąc. Z kolei przestępstwa skarbowe zostały określone w kodeksie karnym skarbowym ${ }^{4}$.

Przestępstwo nawoływania do zbrodni lub występków ma charakter formalny. Nie musi więc wystąpić skutek w postaci dokonania zabójstwa, pobicia czy kradzieży.

W Polsce, zgodnie z prawodawstwem unijnym, powinno być karalne nawoływanie do przestępstw o charakterze terrorystycznym. Przestępstwem o charakterze terrorystycznym jest czyn zabroniony zagrożony karą pozbawienia wolności, której górna granica wynosi co najmniej 5 lat, popełniony w celu:

- poważnego zastraszenia wielu osób;

- zmuszenia organu władzy publicznej Rzeczypospolitej Polskiej lub innego państwa albo organu organizacji międzynarodowej do podjęcia lub zaniechania określonych czynności;

- wywołania poważnych zakłóceń w ustroju lub gospodarce Rzeczypospolitej Polskiej, innego państwa lub organizacji międzynarodowej,

- a także groźba popełnienia takiego czynu (art. $115 \$ 20$ k.k.).

Natomiast zgodnie z art. 255a. k.k. kto rozpowszechnia lub publicznie prezentuje treści mogące ułatwić popełnienie przestępstwa o charakterze terrorystycznym w zamiarze, aby przestępstwo takie zostało popełnione, podlega karze pozbawienia wolno-

2 J. Makarewicz, Kodekskarny z komentarzem, red. nauk. A. Grześkowiak, K. Wiak, Lublin 2012, s. 407, Publikacje Katedry Prawa Karnego KUL.

3 Z. Ćwiąkalski, Rozdziat XXXII, [w:] Kodeks karny. Częś́ szczególna. Komentarz, t. 2: Komentarz do art. 117-277 k.k., red. A. Zoll, Warszawa 2008, s. 1171, Komentarze - Wolters Kluwer Polska.

4 Ustawa z dnia 10 września 1999 r. Kodeks karny skarbowy, Dz. U. 2007, nr 111, poz. 765 z późn. zm. 
ści od 3 miesięcy do lat 5. Czyn ten został stypizowany ustawą z dnia 29 lipca 2011 r. ${ }^{5}$ Wprowadzono go z jednej strony na podstawie prawa unijnego do tego zobowiązującego, a z drugiej na podstawie ratyfikowanej konwencji Rady Europy ${ }^{6}$. Decyzja ramowa Rady 2008/919/WSiSW z 28 listopada 2008 r. zmieniająca decyzję ramową 2002/475/WSiSW w sprawie zwalczania terroryzmu ${ }^{7}$ definiowała, że publiczne nawotywanie do popetniania przestępstw terrorystycznych oznacza rozpowszechnianie lub inną formę udostępniania publicznego przekazu w celu podżegania do popełnienia jednego z przestępstw wymienionych w art. 1 ust. 1 lit. a)-h), jeżeli takie postępowanie, niezależnie od tego, czy stanowi bezpośrednie nakłanianie do popełnienia przestępstw terrorystycznych, powoduje zagrożenie popełnienia co najmniej jednego spośród enumeratywnie wyliczonych przestępstw, m.in. ataku na życie ludzkie, które mogą powodować śmierć8.

Dobrem prawnie chronionym na gruncie naszego art. 255a k.k. jest porządek publiczny, zgodnie z systematyką i umieszczeniem tego typu czynu zabronionego w rozdziale kodeksu karnego, który ma na celu jego ochronę. Nie ma wątpliwości, że w przypadku przestępstw terrorystycznych oraz nawoływania do nich dochodzi do naruszenia panującego ładu w stopniu bardzo wysokim. Jednak oprócz tego dobrem prawnie chronionym jest życie, mienie, bezpieczeństwo i interesy polityczne oraz gospodarcze państwa.

Czynność sprawcza polega na rozpowszechnianiu lub publicznym prezentowaniu. Należy zauważyć, że każde publiczne prezentowanie mieści się w rozpowszechnianiu. Jedynie pojęcie rozpowszechniania jest w tym przypadku szersze, gdyż obejmuje również przypadki zachowania niepublicznego.

$\mathrm{Z}$ kolei znamię treści mogące utatwić popetnienie przestępstwa o charakterze terrorystycznym wskazuje, że ustawodawcy polskiemu wcale nie chodziło o penalizowanie nawoływania do popełnienia przestępstw terrorystycznych. Owe rozpowszechniane lub publicznie prezentowane treści mają bowiem na celu jedynie ułatwienie tego przestępstwa, a nie namawianie innych osób do wzięcia w nim udziału czy do ataków na inne osoby bądź ich mienie oraz na funkcjonowanie państwa. Będzie tu więc chodziło na przykład o rozpowszechnianie instrukcji skonstruowania bomby czy zorganizowania ataku na jakiś obiekt. Natomiast poza zakresem tego typu czynu pozostanie stricte za-

5 Ustawa o zmianie ustawy - Kodeks karny, ustawy - Kodeks postępowania karnego oraz ustawy o odpowiedzialności podmiotów zbiorowych za czyny zabronione pod groźbą kary, Dz. U. 2011, nr 191, poz. 1135.

$6 \quad$ Konwencja o zapobieganiu terroryzmowi z dnia 16 maja 2005 r., która zostata ratyfikowana ustawa z 7 września 2007 r., Dz. U. 2007, nr 191, poz. 1364.

7 http://eur-lex.europa.eu/Notice.do?val=484525:cs\&lang=pl\&list=506356:cs,485148:cs,484525:cs, $477274: c s, 476590: c s, 476589: c s, 469543: c s, 469542: c s, 467249: c s, 454032: c s, \& p o s=3 \& p a g e=2 \& n-$ $\mathrm{bl}=42 \&$ pgs $=10 \&$ hwords $=$ terrory ${ }^{*} \sim$ \&checktexte $=$ checkbox\&visu=\#texte, 26 X 2012.

8 Decyzja ramowa Rady z dnia 13 czerwca 2002 r. w sprawie zwalczania terroryzmu (2002/475/ WSiSW), [online] http://eur-lex.europa.eu/Notice.do?val=274049:cs\&lang=pl\&list=405482:cs,396255:cs, 287326:cs, 286968:cs, 285541:cs, 284772:cs, 276105:cs, 274049:cs,262032:cs, 262031:cs, \&pos $=8 \&$ page $=4 \& \mathrm{nbl}=42 \&$ pgs $=10 \&$ hword $s=$ terrory $* \&$ checktexte $=$ checkbox $\& v i s u=\#$ texte, $26 \times 2012$. 
chęcanie do wstępowania w szeregi ugrupowań terrorystycznych czy nawoływanie do ataku. Z punktu widzenia decyzji ramowej, którą Polska miała wcielić w życie na swoim terytorium, jest to niewłaściwa regulacja.

Art. $256 \$ 1$ k.k. penalizuje publiczne nawoływanie do nienawiści na tle różnic narodowościowych, etnicznych, rasowych, wyznaniowych albo ze względu na bezwyznaniowość i przewiduje za ten czyn karę grzywny, ograniczenia wolności albo pozbawienia wolności do lat 2 . Natomiast zgodnie z art. 126a k.k. kto publicznie nawołuje do popełnienia czynu określonego między innymi w art. 119 k.k., a więc m.in. do stosowania przemocy wobec grupy osób lub poszczególnej osoby z powodu jej przynależności narodowej, etnicznej, rasowej, politycznej, wyznaniowej lub jej bezwyznaniowości podlega karze pozbawienia wolności od 3 miesięcy do lat 5.

Umiejscowienie obu wyżej wymienionych typów czynów zabronionych w kodeksie karnym jest zróżnicowane. Art. 256 k.k. znajduje się w rozdziale Przestępstwa przeciwko porządkowi publicznemu. Dobrem prawnie chronionym jest więc pewien ustalony porządek społeczny, porządek demokratycznego państwa prawa, w którym ludzie różnych narodowości, wyznań i ras mogą żyć obok siebie bez obawy o własne zdrowie czy mienie. $\mathrm{Z}$ tego względu zakazane jest szerzenie poglądów, które mogą skutkować brakiem takiego pokojowego, zgodnego współżycia'. W sytuacji, gdy dojdzie już do zamachu na zdrowie, życie czy mienie danej osoby dochodzi do realizacji odmiennego typu czynu zabronionego. Na gruncie art. 256 k.k. odpowiedzialności karnej podlega samo rozpowszechnianie poglądów, które potencjalnie mogą wywrzeć taki skutek. Jednak, jak pokazały wydarzenia lat 90 . na całym świecie, w tym w Europie, taka penalizacja jest jak najbardziej uzasadniona.

Biorąc pod uwagę treść art. 126a k.k. w związku z art. 119 k.k. oraz art. 256k.k. Polska nie spełniła wymogów umów międzynarodowych. Zgodnie z art. 4 Konwencji z 7 marca 1966 r. w sprawie eliminacji wszelkich form dyskryminacji rasowej ${ }^{10}$ jesteśmy zobowiązani do wprowadzenia karalności podżegania do dyskryminacji rasowej.

Uważam, że dyskryminacja, nienawiść (silne uczucie niechęci, wrogości do kogoś lub czegoś $\left.^{11}\right)$ i przemoc to trzy typy stopniowalnych zachowań. Dyskryminacja jest pierwszym symptomem, pierwszą oznaką niechęci, która może później przybrać formę nienawiści, a następnie przemocy. Sądzę, że powinno się penalizować zachowanie, które może mieć nieodwracalne skutki. Nawoływanie do zróżnicowanego traktowania antagonizuje bowiem społeczeństwo. Zachowanie spokoju, dobrobyt państwa i jego obywateli zależy od równego traktowania wszystkich.

„Pochwalanie” jako znamię sprawcze czynu zabronionego występuje w art. $117 \$ 3$ k.k., zgodnie z którym kto publicznie pochwala wszczęcie lub prowadzenie takiej wojny, podlega karze pozbawienia wolności od 3 miesięcy do lat 5. Kolejnym przepisem, w którym to znamię występuje, jest art. 126a k.k., który penalizuje pochwalanie ściśle

Zob. Z. Ćwiąkalski, dz. cyt., s. 1175.

10 Miedzynarodowa konwencja w sprawie likwidacji wszelkich form dyskryminacji rasowej, otwarta do podpisu w Nowym Jorku dnia 7 marca 1966 r., Dz. U. 1969, nr 25, poz. 187.

11 Stownik jezzyka polskiego, red. nauk. M. Szymczak, t. 2: L-P, Warszawa 1988, s. 342. 
określonych zbrodni przeciwko ludzkości i przestępstw wojennych. Natomiast art. 255 $\$ 3$ k.k. stanowi, że kto publicznie pochwala popełnienie przestępstwa, podlega grzywnie do 180 stawek dziennych, karze ograniczenia wolności albo pozbawienia wolności do roku.

„Pochwalać” oznacza uznawać za stuszne, dobre, wtaściwe, aprobować12. Zachowanie przestępne zostanie więc zrealizowane, jeżeli jego sprawca będzie pochwalał określone zachowania, np. popelnienie przestępstwa. Pochwata to nic innego jak dodatnia ocena czynu. Pochwata jest zachętą do naśladownictwa popetnionego czynu, wskazuje, że przestepstwo jest czynem zastugujacym na uznanie ${ }^{13}$.

A contrario nie będzie stanowiło przestępstwa zachowanie polegające na usprawiedliwianiu popełnionego czynu zabronionego. Nie jest to bowiem jego pochwała, ale wysuwanie argumentów, że sprawca w danych konkretnych okolicznościach miał prawo zachować się tak, jak się zachował. Usprawiedliwiając czyn, usprawiedliwiamy jego sprawcę, co prowadzi w jakiś sposób do usprawiedliwienia samego przestępstwa czy systemu i deprecjonowania ich ofiar.

Pochwalanie zgodnie z brzmieniem art. $255 \$ 3 \mathrm{k} . \mathrm{k}$. dotyczy przestępstwa, a nie czynu zabronionego, a w przypadku art. $117 \$ 3$ k.k. karalne jest pochwalanie wszczęcia lub prowadzenia wojny napastniczej. Z kolei art. 126 a k.k. przewiduje karalność pochwalania ściśle określonych czynów. Jest to dość znacząca różnica, która wpływa na zakres kryminalizacji. W art. $255 \$ 3 \mathrm{k} . \mathrm{k}$. pochwalanie dotyczy przestępstwa, a więc zachowania, które jest karygodne, bezprawne i zawinione oraz które realizuje znamiona typu czynu zabronionego. Przestępstwo może zostać stwierdzone jedynie w wyroku sądu. Jeżeli więc sąd nie uznał danego czynu za przestępstwo, jego pochwalanie nie stanowi realizacji znamion czynu zabronionego określonego w art. $255 \$ 3$ k.k. Natomiast w przypadku pochwalania wszczęcia lub prowadzenia wojny napastniczej nie jest konieczne stwierdzenie przez jakiś międzynarodowy organ, że mamy do czynienia właśnie z taką wojną. To sąd, stosując art. $117 \$ 3$ k.k., musi samodzielnie ustalić istnienie takiej wojny. W przypadku stosowania art. 126 a k.k. wystarczy, że dojdzie do popełnienia określonego czynu, który suma summarum nie musi ostatecznie zostać uznany za przestępstwo. $Z$ tego względu uważam, że ustawodawca powinien zastąpić znamię „przestępstwo” występujące w art. $255 \$ 3$ k.k. znamieniem „zbrodni lub występku”.

Pochwalanie może również przybrać formę sondaży czy pochwalnych tytułów prasowych. Nie tak dawno doszło do zabicia znanego terrorysty. W Stanach Zjednoczonych prasa, prezentując opinie społeczne, pochwalała ten czyn, który sam w sobie jest przestępstwem, o ile zostanie to stwierdzone przez sąd. Również w Polsce pojawiały się podobne opinie. Nie było to nic innego, jak pochwalanie popełnienia czynu zabronionego. W praktyce nie zostało jednak wszczęte żadne postępowanie karne za aprobowanie tego typu walki z terroryzmem.

12 Stownik jezyka polskiego, t. 2, s. 716.

13 R. A. Stefański, Przestępstwo publicznego nawotywania do popetnienia przestępstwa (art. 255 k.k.), „Prokuratura i Prawo” 2006, nr 1, s. 17. 
Art. $256 \$ 1$ k.k. przewiduje, że kto publicznie propaguje faszystowski lub inny totalitarny ustrój państwa, podlega grzywnie, karze ograniczenia wolności albo pozbawienia wolności do lat 2.

Zgodnie ze Stownikiem jezyka polskiego „propagować” oznacza szerzyć, upowszechniać idee, hasta, myśli; zjednywać kogoś dla jakieś idei, akcji itp.; prowadzić propagandę $e^{14}$. Sąd Najwyższy ${ }^{15}$ uznał, że propagowanie, w rozumieniu art. 256 k.k., oznacza każde zachowanie polegające na publicznym prezentowaniu faszystowskiego lub innego totalitarnego ustroju państwa w zamiarze przekonania do niego. Trafnie zwraca uwagę na konieczność wystąpienia „zamiaru przekonania”. Różnicuje on bowiem zwykłe rozpowszechnianie od propagowania. Jednak należy podkreślić, że propagowanie polega na prezentowaniu określonych poglądów przez ich zwolennika z zamiarem przekonania do tych poglądów. Uważam więc, że działanie w każdym innym celu, np. osiągnięcia korzyści majątkowej czy informacyjnej, wyłącza realizację znamion czynu zabronionego i nie jest karalnym propagowaniem.

Zgodnie z art. $256 \$ 2$ k.k. tej samej karze podlega, kto w celu rozpowszechniania produkuje, utrwala lub sprowadza, nabywa, przechowuje, posiada, prezentuje, przewozi lub przesyła druk, nagranie lub inny przedmiot, zawierające treść określoną $\mathrm{w} \$ 1$.

$\$ 3$ art. 256 k.k. wprowadza okoliczność kontratypową. Mianowicie zgodnie z tym przepisem nie popełnia przestępstwa sprawca czynu zabronionego określonego w $\$ 2$, jeżeli dopuścił się tego czynu w ramach działalności artystycznej, edukacyjnej, kolekcjonerskiej lub naukowej. Jednak $\$ 2$ art. 256 k.k. nie dotyczy karalnego propagowania, a jedynie produkowania, utrwalania, sprowadzania, nabywania, przechowywania, posiadania, prezentowania, przewożenia lub przesyłania. Jeżeli więc powyższe zachowanie nastąpi w ramach ściśle określonej działalności, sprawca nie poniesie odpowiedzialności karnej z uwagi na wystąpienie okoliczności usprawiedliwiającej takie zachowanie - kontratypu. Problem polega jednak na tym, że trudno zdefiniować na przykład działalność artystyczną. Trafnie w doktrynie ${ }^{16}$ zauważa się, że noszenie koszulki z zakazaną symboliką może być tłumaczone jakimś artystycznym manifestem.

Na podstawie $256 \$ 2$ k.k. karalnych jest wiele czynności, muszą one jednak zostać dokonane w celu rozpowszechnienia. Nie poniesie więc odpowiedzialności karnej osoba, która dla zaspokojenia własnej ciekawości nabyła i posiada np. Mein Kampf Adolfa Hitlera. Nie musi się ona powoływać na okoliczność kontratypową, gdyż w ogóle nie dochodzi do realizacji znamion czynu.

Jeśli natomiast egzemplarz takiej książki posiada dziennikarz, który wykorzystuje ją do przygotowania materiału prasowego, a więc ewidentnie działa w celu rozpowszechnienia, nie ma żadnej możliwości wyłączenia odpowiedzialności karnej, gdyż działalności dziennikarskiej nie można nazwać artystyczną, edukacyjną, kolekcjo-

$14 \quad$ Stowniki jezzyka polskiego, t. 2, s. 937.

15 Uchwata Sądu Najwyższego - Izba Karna z dnia 28 marca 2002 r., I KZP 5/2002, „LexPolonica”, nr 354410 .

16 E. Pływaczewski, A. Sakowicz, Rozdziat XXXII, [w:] Kodeks karny. Część szczególna, t. 2: Komentarz do artykutów 222-316, red. A. Wąsek, R. Zawłocki, Warszawa 2010, s. 491, Duże Komentarze Becka. 
nerską lub naukową. W przypadku przygotowywania materiału np. na temat „polskich faszystów" dziennikarz, który musi opierać się na pisanym materiale źródłowym, może ponieść odpowiedzialność karną. Jest to niewątpliwie mankament tego przepisu. Należy bowiem zauważyć, zgodnie z tym, o czym pisałam wyżej, rozpowszechnianie jest zachowaniem odmiennym od propagowania. Nawet jeżeli dziennikarz działa w celu krytykowania pewnych grup czy wskazywania społeczeństwu, że mogą one być niebezpieczne, jego podstawowym celem nadal jest rozpowszechnienie - czyli realizuje znamiona czynu zabronionego opisanego w art. $256 \$ 2$ k.k. Przepis ten jest więc źle skonstruowany. Powinno w nim być zakazane określone działanie w celu propagowania, skoro w ust. 1 zakazane jest właśnie propagowanie, a nie rozpowszechnianie.

\section{KARALNA ZNIEWAGA}

Na gruncie polskiego kodeksu karnego istnieje kilka typów czynów zabronionych, których czynność wykonawcza polega na znieważeniu. Przede wszystkim - art. 216 k.k., który typizuje czyn polegający jedynie na naruszeniu godności osobistej człowieka. Jednak oprócz tego znieważanie jako czynność sprawcza występuje w następujących czynach zabronionych:

- art. 133 k.k - zniewaga Narodu lub Rzeczpospolitej Polskiej;

- art. $135 \$ 2$ k.k. - zniewaga Prezydenta Rzeczypospolitej Polskiej;

- art. $136 \$ 3$ k.k. - zniewaga głowy obcego państwa lub akredytowanego szefa przedstawicielstwa dyplomatycznego takiego państwa, albo osoby korzystającej z podobnej ochrony na mocy ustaw, umów lub powszechnie uznanych zwyczajów międzynarodowych;

- art. $136 \$ 4$ - zniewaga osoby należącej do personelu dyplomatycznego przedstawicielstwa obcego państwa albo urzędnika konsularnego obcego państwa;

- art. $137 \$ 1$ k.k. - zniewaga godła, sztandaru, chorągwi, bandery, flagi lub innego znaku państwowego;

- art. $137 \$ 2$ k.k. - zniewaga godła, sztandaru, chorągwi, bandery, flagi lub innego znaku państwa obcego, wystawionego publicznie przez przedstawicielstwo tego państwa lub na zarządzenie polskiego organu władzy;

- art. 196 k.k. - obraza uczuć religijnych innych osób poprzez zniewagę przedmiotów czci religijnej lub miejsc przeznaczonych do publicznego wykonywania obrzędów religijnych;

- art. $226 \$ 1$ k.k. - zniewaga funkcjonariusza publicznego lub osoby do pomocy mu przybranej, podczas i w związku z pełnieniem obowiązków służbowych;

- art. $226 \$ 3$ k.k. - zniewaga lub poniżenie konstytucyjnego organu Rzeczypospolitej Polskiej;

- art. 257 k.k. - zniewaga grupy ludności albo poszczególnej osoby z powodu jej przynależności narodowej, etnicznej, rasowej, wyznaniowej albo jej bezwyznaniowości; 
- art. 261 k.k. - zniewaga pomnika lub innego miejsca publicznego urządzonego w celu upamiętnienia zdarzenia historycznego lub uczczenia osoby;

- art. $262 \$ 1$ k.k. - zniewaga zwłok, prochów ludzkich lub miejsca spoczynku zmarłego.

Z powyższego zestawienia wynika, że czynów polegających na znieważeniu jest sporo. Łączy je sposób ich dokonania, odmienne są natomiast przedmioty czynności wykonawczej (choć nie zawsze), dobro prawnie chronione oraz znamiona modalne, gdyż część z nich wymaga działania publicznego.

Zgodnie ze Stownikiem jezzyka polskiego "znieważyć" oznacza ubliżý komuś, zachować się względem kogoś w sposób obraźliwy; zelżyć kogoss ${ }^{17}$. Uważam, że znieważenie polega na wystawieniu komuś negatywnej oceny w sposób obraźliwy, tendencyjny lub bez jakiejkolwiek podstawy faktycznej albo sprzecznie z nią. Należy bowiem pamiętać o tym, że oceny zasadniczo pozostają pod ochroną prawa, jeśli są rzetelne, zgodne z zasadami współżycia społecznego. $Z$ tego wynika wniosek, że znieważać mogą jedynie takie, których forma wykracza poza to, co społecznie akceptowalne, oraz nieoparte na prawdziwej podstawie. Zdaniem Witolda Kuleszy przepis prawa karnego chroni godność cztowieka - rozumiana jako stan dany kazdemu podmiotowi - przed takimi naruszeniami, które wedtug zdeterminowanych kulturowo i powszechnie przyjetych ocen stanowia wyraz pogardy dla cztowieka niezależnie od odczuć samego pokrzywdzonego ${ }^{18}$. Zniewaga to takie zachowanie, które uwtacza godności przystugującej każdemu cztowiekowi z racji jego cztowieczeństwa ${ }^{19}$.

Zniewaga może przybrać formę publikacji prasowej, wypowiedzi w radiu czy telewizji, może więc zostać dokonana za pomocą słowa, pisma, fotografii, karykatury, a nawet gestu. $Z$ tego wynika, że zasadniczo czyn ten może zostać dokonany jedynie z działania ${ }^{20}$, chociaż nie wyklucza również w tym przypadku zaniechania.

O tym, czy mamy do czynienia ze znieważeniem, decydują ogólne normy zachowania obowiązujące w społeczeństwie. Jednak niekiedy należy również wziąć pod uwagę oceny istniejące w poszczególnych grupach społecznych, do których pokrzywdzony należy ${ }^{21}$. Oceny te mogą być odmienne od funkcjonujących w innych grupach społecznych.

Obowiązuje natomiast ogólna zasada wypracowana przez Europejski Trybunał Praw Człowieka, że polityk musi mieć grubszą skórę, niż inni członkowie społeczeństwa, a podejmując decyzję o zostaniu politykiem, musi się liczyć z „niewybredną” i prostacką krytyką. Określenie: babsztyl tże bez wstydu, użyte wobec jednej z posłanek przez „Super Express” jest jednak moim zdaniem niedopuszczalną krytyką cudzego za-

17 Stownik języka polskiego, t. 3: R-Ż, Warszawa 1989, s. 1049.

18 W. Kulesza, Zniestawienie i zniewaga (ochrona czci i godności osobistej cztowieka w polskim prawie karnym - zagadnienia podstawowe), Warszawa 1984, s. 169.

19 I. Andrejew, W. Świda, W. Wolter, Kodeks karny z komentarzem, Warszawa 1973, s. 530.

20 Tamże.

21 J. Wojciechowski, Objaśnienia do art. 212-217, [w:] Kodeks karny. Częśćszczególna, t. 1: Komentarz do artykutów 117-221, red. A. Wąsek, R. Zawłocki, Warszawa 2010, s. 1347-1348. 
chowania, a więc zniewagą, która w tym przypadku nawet przybrała formę obelżywą. Podobnie użycie słów hochsztapler, przestępca i wyjątkowy szkodnik polityczny w stosunku do wicepremiera; farsa, mam wrażenie, że wyrok byt z góry ustalony wobec sądu lustracyjnego przez Józefa Oleksego; panowie po prostu z tchórzostwa, skrajnego tchórzostwa i oportunizmu wstrzymali się od zabrania gtosu [...] to haniebny epizod w dziejach tego Trybunatu - wszystko to jest zniewagą. Niewątpliwie wulgarny charakter miało także sformułowanie Prokurator Podupadty poprzez wyeksponowanie przy pomocy techniki drukarskiej słów powszechnie uznanych za obelżywe. Z kolei Prokurator Prokuratury Okręgowej w Warszawie postanowieniem z 18 kwietnia 2005 r. (V Ds. 105/2005) trafnie odmówił wszczęcia śledztwa w sprawie publicznego znieważenia Prezydenta RP przez publikację w jednym z ogólnopolskich tygodników artykułu, w którym Prezydent $\mathrm{RP}$ został określony jako prezydent wszystkich aferzystów.

Europejski Trybunał Praw Człowieka w stosunku do polityków dopuszcza nawet wulgarną krytykę, ale musi ona odnosić się do poglądów prezentowanych przez danego polityka, a nie poniżać go jako człowieka. Dlatego Europejski Trybunał Praw Człowieka zaakceptował użycie określenia idiota przez dziennikarza w odniesieniu do polityka $\mathrm{z}$ racji prezentowanych przez niego poglądów i wypowiedzi ${ }^{22}$. Jednak również w sprawach budzących publiczne zainteresowanie Trybunał akceptuje dosadne oceny, na przykład sformułowanie świństwo w odniesieniu do chipsów Star Foods ${ }^{23}$. W sprawie Długołęcki przeciwko Polsce ${ }^{24}$ sądy w Polsce uznały za znieważenie opinię: doszedt juz kilka lat temu do szczytu swojej niekompetencji, lecz ten btąd podnosi go na jeszcze wyższy poziom niekompetencji, i warunkowo umorzyły postępowanie wobec skarżącego właśnie z art. $216 \$ 2$ k.k. Trybunał przypomniał, że politycy muszą się liczyć nawet z przesadnymi ocenami swojego postępowania, a zwłaszcza w okresie wyborczym. Uznano ponadto, że ocena dokonana w czasopiśmie nie była pozbawiona podstaw. Przyjęto więc naruszenie przez Polskę art. 10 Europejskiej Konwencji Praw Człowieka i Podstawowych Wolności, pomimo łagodnej sankcji. W kontekście zniewagi można również rozpatrywać sprawę Sanocki przeciwko Polsce ${ }^{25}$. Janusz Sanocki, burmistrz jednego z miast, był krytykowany przez gazetę „Nowa Trybuna Opolska”. W odpowiedzi opublikował w innej gazecie materiał prasowy krytykujący NTO. Sądy krajowe (cywilne) uznały, że sformułowania użyte w artykule skarżącego, takie jak tradycyjna metoda bolszewików - donos + ktamstwo czy „Nowa Trybuna Opolska” sieggnie

22 Wyrok z dnia 01 lipca 1997 r., Oberschlick przeciwko Austrii, [online] http://hudoc.echr.coe.int/, 15 VIII 2012.

23 Wyrok z dnia 06 października 2009 r., Kuliś i Różycki przeciwko Polsce, [online] http://bip.ms.gov. $\mathrm{pl} / \mathrm{pl} /$ prawa-czlowieka/europejski-trybunal-praw-czlowieka/orzecznictwo-europejskiego-trybunalu-praw-czlowieka/orzeczenia-w-sprawach-dotyczacych-polski/rok-2009/, 15 VIII 2012.

24 Wyrok Europejskiego Trybunatu Praw Cztowieka z dnia 24 lutego 2009 r., [online] http://bip.ms.gov. $\mathrm{pl} / \mathrm{pl} /$ prawa-czlowieka/europejski-trybunal-praw-czlowieka/orzecznictwo-europejskiego-trybunalu-praw-czlowieka/orzeczenia-w-sprawach-dotyczacych-polski/rok-2009, 15 VIII 2012.

25 Wyrok z dnia 17 lipca 2007, Sanocki przeciwko Polsce, [online] http://bip.ms.gov.pl/pl/prawa-czlowieka/europejski-trybunal-praw-czlowieka/orzecznictwo-europejskiego-trybunalu-praw-czlowieka/orzeczenia-w-sprawach-dotyczacych-polski/rok-2007/, 15 VIII 2012. 
wkrótce putapu rynsztoka, jak również sugerowanie, że dziennik publikuje kłamliwe informacje, miały charakter poniżający dla wydawcy. Trybunał uznał, że zwroty te są pozbawione elegancji, ale $\mathrm{w}$ dziedzinie debaty politycznej zniewaga wkracza często na plan osobisty: jest to ryzyko związane z grą polityczną i wolną ideową debatą, gwarantami społeczeństwa. Przyjął przy tym, że skoro swoboda wypowiedzi dziennikarza zawiera możliwość zastosowania pewnej dozy przesady, a nawet prowokacji, polityk, który odpowiada na łamach prasy na krytykę wyrażoną w stosunku do niego, powinien mieć możliwość odpowiedzi według tych samych zasad. Dlatego Trybunał uznał, że Polska naruszyła art. 10 Europejskiej Konwencji Praw Człowieka i Podstawowych Wolności.

\section{a. Zniewaga Prezydenta Rzeczypospolitej Polskiej}

Zgodnie z art. $135 \$ 2$ k.k. kto publicznie znieważa Prezydenta Rzeczypospolitej Polskiej, podlega karze pozbawienia wolności do lat 3. Już na wstępie należy zaznaczyć, że współcześnie takie zagrożenie karne, bez możliwości zasądzenia innej kary (grzywny lub ograniczenia wolności), jest anachroniczne ${ }^{26}$. Trybunał Konstytucyjny rozważał już kwestię zgodności art. $135 \$ 2$ k.k. z Konstytucją i uznał, że nie narusza on art. 31 i art. 54 Konstytucji ani art. 10 Europejskiej Konwencji Praw Człowieka i Podstawowych Wolności. Przyjęto ponadto, że sankcja ta nie jest nieproporcjonalna do chronionego dobra prawnie chronionego, ponieważ sąd może skorzystać z art. 58 $\$ 3$ k.k. i art. 59 k.k., by wymierzyć karę grzywny, ograniczenia wolności lub jedynie środek karny.

Zawsze więc, gdy ustawodawca przewidział karę do 3 lat pozbawienia wolności, może wchodzić w grę zastosowanie art. $58 \$ 3$ k.k. Dlaczego w takim razie alternatywa nie znalazła się już w normie sankcjonującej? Takie ułożenie może być odczytywane następująco: pozbawienie wolności jest podstawową sankcją karną, a pozostałe kary są wyjątkiem od reguły, które mogą być stosowane, gdy dyrektywy wymiaru kary na to pozwalają, w specyficznych okolicznościach. W praktyce jest natomiast na odwrót. Przede wszystkim jest to niezrozumiałe dla osób niebędących prawnikami, w tym dziennikarzy, którzy nie znają się na ogólnych instytucjach prawa karnego, a przepis odczytują wprost, nie zaglądając do części ogólnej kodeksu karnego. Nie sprzyja to zrozumieniu prawa przez ogół społeczeństwa w zakresie wymiaru kary. Nie mam natomiast żadnych wątpliwości, że sankcja karna przewidziana w art. $135 \$ 2$ k.k. działa hamująco na wolność wypowiedzi. Należy przy tym zauważyć, że w Europie istnieje raczej tendencja do odchodzenia od kar izolacyjnych w sytuacji zniewag i zniesławienia. Tego typu kary nie mają bowiem żadnego uzasadnienia, a są wykonywane na koszt podatników.

Dobrem prawnie chronionym jest godność Rzeczypospolitej Polskiej, której głową jest jej prezydent i jej interesy. Jeżeli nie będzie poważana najważniejsza jej osoba,

26 Na podstawie art. 58 i 59 k.k. sąd ma możliwość zasądzenia grzywny lub kary ograniczenia wolności albo poprzestania na wymierzeniu środków karnych. Jednak taka możliwość wynika już ze szczegółowych zasad wymiaru kary, a nie bezpośrednio z art. $135 \$ 2$ k.k. 
to i ona sama nie będzie miała szacunku, dlatego konieczna jest ochrona prezydenta, choćby nawet on sam na szacunek nie zasługiwał. Każdy prezydent jest wybierany przez Naród i wybór ten należy poważać. Uważa się, że doniosłość wykonywanych przez niego funkcji powinna automatycznie skutkować tym, że należy się mu szacunek. Jednak współcześnie taka ochrona może budzić wątpliwości; prezydent jest zasadniczo przede wszystkim politykiem, który rozgrywa własne interesy. Ponadto, jak pokazuje przypadek prezydenta Nicolas Sarkozy’ego, prezydent może zachowywać się w sposób grubiański, prowokując niewybredne ataki. Należy przy tym zauważyć, że w przypadku prezydenta brak jest możliwości odstąpienia od wymierzenia kary ze względu na zniewagę wzajemną. Trudno w jakikolwiek sposób uzasadnić ochronę prezydenta, który posługuje się językiem powszechnie uznanym za wulgarny w stosunku do swoich przeciwników politycznych; oni sami mają ograniczoną możliwość obrony przed takim atakiem ze względu na art. $135 \$ 2$ k.k.

\section{b. Zniewaga konstytucyjnego organu Rzeczypospolitej Polskiej}

Zgodnie z art. $226 \$ 3$ k.k. kto publicznie znieważa lub poniża konstytucyjny organ Rzeczypospolitej Polskiej, podlega grzywnie, karze ograniczenia wolności albo pozbawienia wolności do lat 2. Przepis ten znajduje się w rozdziale XXIX zatytułowanym Przestępstwa przeciwko dziatalności instytucji państwowych oraz samorządu terytorialnego.

Dobrem chronionym na gruncie tego przepisu jest przede wszystkim autorytet organów władzy publicznej oraz porządek publiczny. Nie jest więc istotne, czy osoby składające się na taki konstytucyjny organ odczują zniewagę, ani nawet to, czy ta do nich dotrze. Subiektywne poczucie znieważenia, a nawet wola - lub jej brak - ukarania sprawcy czynu nie ma znaczenia. Świadczy o tym również sam tryb ścigania. Przestępstwo to należy bowiem do ściganych z urzędu. Każde państwo ma prawo chronić w ten sposób swój autorytet i ograniczać wolność wypowiedzi. W określonych sytuacjach władza powinna mieć zagwarantowany pewien poziom spokoju w realizowaniu swoich kompetencji i nie powinna być narażona na poniżające traktowanie właśnie dlatego, że działa w imieniu państwa. Istotne jest bowiem efektywne i niezakłócone działanie organów władzy publicznej w interesie ogółu społeczeństwa.

Przedmiotem czynności wykonawczej jest organ konstytucyjny. Organy konstytucyjne to takie, których byt i kompetencja do określonych działań wynikają bezpośrednio z Konstytucji. Należy do nich zaliczyć: Sejm, Senat, Zgromadzenie Narodowe, Marszałka Sejmu, Marszałka Senatu, komisję śledczą ${ }^{27}$, prezydenta (jednak jego ochrona przed zniewagą następuje na podstawie art. $135 \$ 2$ k.k., który jest przepisem szczególnym w odniesieniu do art. $226 \$ 2$ k.k.), Radę Ministrów, Prezesa Rady Ministrów, Wiceprezesa Rady Ministrów, ministrów, przewodniczących określonych w usta-

Zob. Wyrok Trybunatu Konstytucyjnego z dnia 22 września 2006 r., U. 4/2006, „LexPolonica”, nr 417461. 
wach komitetów, jednostki samorządu terytorialnego, regionalne izby obrachunkowe, sądy, Sąd Najwyższy, Naczelny Sąd Administracyjny, trybunały (Konstytucyjny, Stanu), Krajową Radę Sądownictwą, Najwyższą Izbę Kontrolii" ${ }^{28}$, Rzecznika Praw Obywatelskich, Rzecznika Praw Dziecka oraz Krajową Radę Radiofonii i Telewizji, Narodowy Bank Polski, Prezesa NBP, Radę Polityki Pieniężnej. Należy zauważyć, że katalog organów konstytucyjnych ma charakter zamknięty.

Na gruncie art. $226 \$ 3$ k.k. czynnością sprawczą obok znieważania jest również poniżanie. Niewątpliwie określeniu temu należy nadać odmienną treść niż znieważaniu. Trafna wydaje się więc interpretacja, że przepis ten swoim zakresem obejmuje również zniesławianie. Wynika to z interpretacji art. $212 \$ 1 \mathrm{k} . \mathrm{k}$. Zniesławianiem jest bowiem poniżanie kogoś w oczach opinii publicznej, a więc podnoszenie zarzutów, które mogą zostać zweryfikowane na podstawie testu prawdy i fałszu. Zniesławienie organu konstytucyjnego powinno być więc kwalifikowane jako zachowanie naruszające art. 226 $\$ 3 \mathrm{k} . k .{ }^{29} \mathrm{~W}$ przypadku wypowiedzi, która jest jednocześnie znieważeniem i zniesławieniem Prezydenta RP, nastąpi zbieg przepisów ustawy: zniewagę będzie należało zakwalifikować $\mathrm{z}$ art. $135 \$ 2 \mathrm{k} . \mathrm{k}$. , a zniesławienie $\mathrm{z}$ art. $226 \$ \mathrm{k} . \mathrm{k}$.

W przypadku art. $226 \$ 3$ k.k. nie ma znaczenia, czy zniewaga lub zniesławienie ma związek z funkcjonowaniem organu, czy też nastąpiła w trakcie trwania jego prac. Istotne jest jedynie, aby miała ona charakter publiczny, a więc aby potencjalnie mogła dotrzeć do nieograniczonej liczby osób lub grupy ograniczonej, ale takiej, której członkowie nie są ze sobą związani prywatnymi więzami towarzyskimi. Dlatego zniewaga lub zniesławienie organu konstytucyjnego może niewątpliwie dość często wystąpić jako przestępstwo prasowe. Należy jednak zwrócić uwagę na tendencję do ograniczania ochrony prawnej, w tym prawnokarnej polityków, a ci są niekiedy jednocześnie organem konstytucyjnym. Uważam więc, że skazanie za zniewagę konstytucyjnego organu kibiców wykrzykujących: Tusk, ty matole, twój rząd obala kibole jest nie na miejscu i narusza art. 10 Europejskiej Konwencji Praw Człowieka i Podstawowych Wolności ${ }^{30}$. Co ciekawe, prokuratura umorzyła postępowanie przeciwko Kubie Wojewódzkiemu i Michałowi Figurskiemu za nazwanie Lecha Kaczyńskiego urzędującego wówczas prezydenta RP matym, upośledzonym, gtupim cztowiekiem zwanym prezydentem Polski ${ }^{31}$.

Za zniewagę organu konstytucyjnego grozi nawet kara pozbawienia wolności do 2 lat. Wprawdzie w Polsce sądy jej nie wymierzają, jednak sama możliwość jej zasądzenia ma skutek hamujący dla wolności wypowiedzi. Uważam, że należy w przypadku również tej zniewagi złagodzić sankcje karne.

28 Zob. Wyrok Trybunatu Konstytucyjnego z dnia 1 grudnia 1998 r., K. 21/98, „LexPolonica”, nr 348067.

29 Zob. Kodeks karny. Komentarz. Częśćszczególna, t. 2, s. 735, 941.

30 Podaję tę informację za: Kibice skazani za ,Tusk ty matole”, [online] http://www.wprost.pl/ar/348777/ Kibice-skazani-za-Tusk-ty-matole/, 23 IX 2012.

31 B. Dreśliński, Prokurator umorzyt śledztwo przeciwko Figurskiemu i Wojewódzkiemu, [online] http:// wiadomosci.gazeta.pl/wiadomosci/1,126765,6840064,Prokurator_umorzyl_sledztwo_przeciwko_ Figurskiem.html, 23 IX 2012. 


\section{c. Zniewaga o charakterze dyskryminacyjnym}

Zgodnie z art. 257 k.k. kto publicznie znieważa grupę ludności albo poszczególną osobę z powodu jej przynależności narodowej, etnicznej, rasowej, wyznaniowej albo jej bezwyznaniowości podlega karze pozbawienia wolności do lat 3. Przepis ten znajduje się w rozdziale zatytułowanym Przestępstwa przeciwko porzadkowi publicznemu.

Rodzajowym dobrem prawnie chronionym jest porządek publiczny. Ustawodawca trafnie bowiem uznał, że zniewaga o charakterze dyskryminacyjnym może doprowadzić do naruszenia równowagi społecznej, a nawet, w skrajnych przypadkach, do zamieszek i niepokojów społecznych. Natomiast konkretnym dobrem prawnie chronionym jest równość wszystkich ludzi ${ }^{32}$. Jeżeli bowiem dopuści się do zniewag na tle dyskryminacyjnym, ta równość zostaje zachwiana - jedni są lepsi, inni gorsi z uwagi na jakąś cechę, która nie ma znaczenia przy podejmowaniu wyboru. Ponadto tolerowanie tego typu zniewag prowadzi do utrwalenia negatywnego stereotypu o danej grupie w społeczeństwie, co w okresie II wojny światowej doprowadziło do ludobójstwa. Dodatkowym przedmiotem ochrony jest godność ludzka ${ }^{33}$.

Jednak polski ustawodawca nie penalizuje wszystkich zniewag o charakterze dyskryminacyjnym, a tylko ściśle określone - ze względu na przynależność narodową, etniczną, rasową, wyznaniową albo bezwyznaniowość. W innych systemach karnych dodatkowo karalna jest zniewaga i zniesławienie ze względu na pochodzenie, płeć, orientację seksualną lub upośledzenie. Natomiast przy porównaniu art. 257 k.k. i art. 119 k.k. widać, że w art. 257 k.k. pominięto zniewagę ze względu na przynależność polityczną.

Przedmiotem czynności wykonawczej jest grupa ludności lub osoba o określonej przynależności narodowej, etnicznej, rasowej, wyznaniowej albo bezwyznaniowa. Nie jestściśle zdefiniowane, jaka minimalna liczba osób stanowi grupę; zdaniem Zbigniewa Ćwiąkalskiego ${ }^{34}$ to trzy osoby. Zniewaga musi nastąpić ze względu na określoną ściśle przynależność.

Ochrona przynależności narodowej, etnicznej, rasowej, wyznaniowej następuje jedynie przed zniewagami. Jeżeli grupa taka zostanie zniesławiona, może dochodzić ochrony tylko na podstawie art. 212 k.k. Będzie więc istotne, czy sprawca stawia zarzut, czy jedynie wygłasza ocenę.

Natomiast sama zniewaga musi nastąpić z powodu przynależności do określonej grupy.

Karą za publiczne znieważenie grupy ludności albo osoby z powodu jej przynależności narodowej, etnicznej, rasowej, wyznaniowej bądź ze względu na jej bezwyznaniowość jest pozbawienie wolności do lat 3. To surowa kara. Sąd również w tym przypadku na podstawie art. 58 k.k. może wymierzyć grzywnę, karę ograniczenia wolności lub nawet poprzestać jedynie na orzeczeniu środków karnych, ale sama możliwość wymierzenia kary w wysokości 3 lat bezwzględnego pozbawienia wolności jest niewspółmierna do czynu i niewątpliwie nadmiernie ogranicza wolność wypowiedzi.

32 I. Andrejew, W. Świda, W. Wolter, dz. cyt., s. 833.

33 Odmiennie na temat dobra prawnie chronionego na gruncie art. 257 k.k. zob. E. Pływaczewski, A. Sakowicz, dz. cyt., s.493-494. Na ten temat zob. również: R. A. Stefański, dz. cyt., s. 25 i n.

34 Z. Ćwiąkalski, dz. cyt., s. 1182. 


\section{PODSUMOWANIE}

Wiele dóbr prawnych musi być chronionych za pomocą norm sankcjonujących. Dlatego dziennikarze czy redaktorzy naczelni muszą się liczyć z ewentualną odpowiedzialnością karną za ich naruszenie. Przepisy te ograniczają wolność wypowiedzi, która jednak nie ma charakteru absolutnego. Uważam, że penalizowanie nadużycia wolności wypowiedzi jest niezbędne we współczesnym społeczeństwie. Jednak anachronizmem jest przewidywanie w niektórych sytuacjach (zniesławienia i zniewagi), w odniesieniu do prasy, możliwości zastosowania sankcji izolacyjnych. Dlatego uważam, że liberalizacja polskiego prawa karnego jest niezbędna.

\section{BIBLIOGRAFIA}

Andrejew I., Świda W., Wolter W., Kodeks karny z komentarzem, Warszawa 1973.

Barta J., Dobosz I., Prawo prasowe, Kraków 1989.

Ćwiąkalski Z., Rozdziat XXXII, [w:] Kodekskarny. Częśśszczególna. Komentarz, t. 2: Komentarz do art. 117-277 k.k., red. A. Zoll, Warszawa 2008, Komentarze - Wolters Kluwer Polska.

Dreśliński B., Prokurator umorzyt śledztwo przeciwko Figurskiemu i Wojewódzkiemu, [online] http://wiadomosci.gazeta.pl/wiadomosci/1,126765,6840064,Prokurator_umorzyl_sledztwo_przeciwko_Figurskiem.html, 23 IX 2012.

http://eur-lex.europa.eu/Notice.do?val=484525:cs\&lang=pl\&list $=506356: \mathrm{cs}, 485148: \mathrm{c}-$ s, $484525: c s, 477274: c s, 476590: c s, 476589: c s, 469543: c s, 469542: c s, 467249: c s, 454032: c-$ $\mathrm{s}, \&$ pos $=3 \&$ page $=2 \& \mathrm{nbl}=42 \&$ pgs $=10 \&$ hwords $=$ terror ${ }^{*} \sim \&$ checktexte $=$ checkbox\&visu =\#texte, 26 X 2012.

Kibice skazani za "Tusk ty matole", [online] http://www.wprost.pl/ar/348777/Kibice-skazani-za-Tusk-ty-matole, 23 IX 2012.

Kodeks karny. Częśś szczególna. Komentarz, t. 2: Komentarz do art. 117-277 k.k., red. A. Zoll, Warszawa 2008, Komentarze - Wolters Kluwer Polska.

Kulesza W., Zniestawienie i zniewaga (ochrona czci i godności osobistej cztowieka w polskim prawie karnym - zagadnienia podstawowe), Warszawa 1984.

Makarewicz J., Kodeks karny z komentarzem, red. nauk. A. Grześkowiak, K. Wiak, Lublin 2012, Publikacje Katedry Prawa Karnego KUL.

Pływaczewski E., Sakowicz A., Rozdziat XXXII, [w:] Kodeks karny. Część szczególna, t. 2: Komentarz do artykutów 222-316, red. A. Wąsek, R. Zawłocki, Warszawa 2010, Duże Komentarze Becka.

Pływaczewski E., Stefański R. A., Przestępstwo publicznego znieważenia ludności lub osoby z powodu dyskryminacyjnego (art. 257 k.k.), „Prokuratura i Prawo” 2006, nr 6.

Stownik jezyka polskiego, red. nauk. M. Szymczak, t. 2: L-P, Warszawa 1988; t. 3: R-Ż, Warszawa 1989.

Stefański R. A., Przestępstwo publicznego nawotywania do popetnienia przestępstwa (art. 255 k.k.), „Prokuratura i Prawo” 2006, nr 1. 
Uchwata Sądu Najwyższego - Izba Karna z dnia 28 marca 2002 r., I KZP 5/2002, „LexPolonica”, nr 354410.

Wojciechowski J., Objaśnienia do art. 212-217, [w:] Kodeks karny. Częśś szczególna, t. 1: Komentarz do artykutów 117-221, red. A. Wąsek, R. Zawłocki, Warszawa 2010, Duże Komentarze Becka.

Wyrok Europejskiego Trybunatu Praw Cztowieka z dnia 24 lutego 2009 r., [online] http:// bip.ms.gov.pl/pl/prawa-czlowieka/europejski-trybunal-praw-czlowieka/orzecznictwo-europejskiego-trybunalu-praw-czlowieka/orzeczenia-w-sprawach-dotyczacych-polski/ rok-2009, 15 VIII 2012.

Wyrok Trybunatu Konstytucyjnego $z$ dnia 1 grudnia 1998 r., K. 21/98, „LexPolonica”, nr 348067.

Wyrok Trybunatu Konstytucyjnego z dnia 22 września 2006 r., U. 4/2006, „LexPolonica”, $\mathrm{nr} 417461$.

Wyrok z dnia 01 lipca 1997 r., Oberschlick przeciwko Austrii, [online] http://hudoc.echr.coe.int, 15 VIII 2012.

Wyrok z dnia 17 lipca 2007, Sanocki przeciwko Polsce, [online] http://bip.ms.gov.pl/pl/prawa-czlowieka/europejski-trybunal-praw-czlowieka/orzecznictwo-europejskiego-trybunalu-praw-czlowieka/orzeczenia-w-sprawach-dotyczacych-polski/rok-2007, 15 VIII 2012.

Wyrokzdnia 06października 2009 r., Kuliśi Różyckiprzeciwko Polsce, [online] http://bip.ms.gov. $\mathrm{pl} / \mathrm{pl} /$ prawa-czlowieka/europejski-trybunal-praw-czlowieka/orzecznictwo-europejskiego-trybunalu-praw-czlowieka/orzeczenia-w-sprawach-dotyczacych-polski/rok-2009, 15 VIII 2012.

Akty prawne i inne regulacje:

Międzynarodowa konwencja w sprawie likwidacji wszelkich form dyskryminacji rasowej, otwarta do podpisu w Nowym Jorku dnia 7 marca 1966 r., Dz. U. 1969, nr 25, poz. 187.

Council Framework Decision of 13 June 2002 r. of... (2002/475/WSiSW), [online] http:// eur-lex.europa.eu/Notice.do $?$ val $=274049: \mathrm{cs} \&$ lang $=$ pl\&list $=405482: \mathrm{cs}, 396255: \mathrm{c}-$ s,287326:cs, 286968:cs,285541:cs,284772:cs,276105:cs,274049:cs, 262032:cs, 262031:c$\mathrm{s}, \&$ pos $=8 \&$ page $=4 \& \mathrm{nbl}=42 \&$ pgs $=10 \&$ hwords $=$ terrory ${ }^{*} \sim \&$ checktexte $=$ checkbox \&visu$=\#$ texte, 26 X 2012.

Ustawa z dnia 10 września 1999 r. Kodeks karny skarbowy, Dz. U. 2007, nr 111, poz. 765 z późn. zm.

Konwencja o zapobieganiu terroryzmowi z dnia 16 maja 2005 r., która zostata ratyfikowana ustawa z 7 września 2007 r., Dz. U. 2007, nr 191, poz. 1364.

Ustawa o zmianie ustawy - Kodeks karny, ustawy - Kodeks postępowania karnego oraz ustawy oodpowiedzialności podmiotów zbiorowych za czyny zabronione pod groźbą kary, Dz. U.2011, nr 191, poz. 1135.

Dr Elżbieta CZARNY-DROŻDŻEJKO, doktor nauk prawnych, adiunkt na Uniwersytecie Jagiellońskim (Zakład Dziennikarstwa INPiSM) oraz na Uniwersytecie Papieskim Jana Pawła II (Katedra Prawa Mediów). 